\title{
sciendo
}

Current Issues in Pharmacy and Medical Sciences

Formerly ANNALES UNIVERSITATIS MARIAE CURIE-SKLODOWSKA, SECTIO DDD, PHARMACIA

\section{Effect of perinatal administration of flavonoid-rich extract from Hibiscus sabdariffa to feed-restricted rats, on offspring postnatal growth and reproductive development}

\author{
Odochi O. Chukwu ${ }^{1}$, Chinedum U. Emelike ${ }^{2 \star} \bullet$, Nwaeze G. Konyefom ${ }^{2}$, \\ Sylvester N. Ibekailo ${ }^{2}$, Sharon O. Azubuike-Osu², \\ Anthony C. U. Ezimah ${ }^{2}$, Eghosa E. Iyare 3 [1]
}

${ }^{1}$ Physiology Unit, College of Health Sciences, Evangel University Akaeze, Ebonyi State, Nigeria

${ }^{2}$ Department of Physiology, Faculty of Basic Medical Sciences, College of Medical Sciences, Alex Ekwueme Federal University, Ndufu-Alike, Abakaliki, Ebonyi State, Nigeria

${ }^{3}$ Department of Physiology, Faculty of Basic Medical Sciences, College of Medicine, University of Nigeria, Enugu Campus, Enugu, Nigeria

\section{ARTICLE INFO}

Received 22 June 2020

Accepted 20 April 2021

\section{Keywords:}

BMI,

development,

estradiol,

flavonoid,

Hibiscus sabdariffa,

testosterone and organs.

\begin{abstract}
Developmental programming is a process where stimulus or insult acting during critical periods of growth and development might permanently alter tissue anatomy and physiology so as to produce adverse effects in adult life. Most forms of exposure include maternal nutrient deprivation, nutrient excess, exogenous glucocorticoid excess and endogenous glucocorticoid due to maternal stress. Hibiscus sabdariffa $(\mathrm{Hs})$ are highly rich in phenolic compounds with marked physiological activities, the sweetened aqueous extract of Hs, commonly known as "Zobo' in Nigeria, is consumed by humans including pregnant and lactating mothers. This study aimed at determining effects of perinatal administration of flavonoid-rich extract from Hs to feed-restricted rats, on offspring postnatal growth and reproductive development. Twenty-five pregnant female rats were used. Rats were randomly placed into five groups of five rats per group (one animal per cage): Group I (Normal control); Group II (feed-restricted control); Group III (5 mg/kg extract $+70 \%$ feed- restricted diet); Group IV $(10 \mathrm{mg} / \mathrm{kg}$ extract $+70 \%$ feed-restricted diet); Group V (20 mg/kg extract $+70 \%$ feed-restricted diet). Dams were allowed to nurse only 8 pups. Pups were weaned to ad libitum feed and water and were observed daily for puberty onset. Weights, lengths and body mass index (BMI) of pups were measured at delivery, weaning and puberty onset. At onset of puberty in each of the rats, blood samples were collected for determination of follicle stimulating hormone (FSH), luteinizing hormone (LH), estradiol and testosterone. Reproductive organs were excised and weighed for histology. The extract caused significant increase in postnatal weight, length and BMI of offspring at birth, weaning and puberty onset and significantly delayed puberty onset in both sexes. There was significant increase in absolute and relative weights of testes and ovaries with alterations in histology. This study has shown that maternal consumption of flavonoid-rich extract of $H s$ during pregnancy and lactation may accelerate offspring postnatal growth with delay in onset of puberty.
\end{abstract}

\section{INTRODUCTION}

The nutritional, hormonal and metabolic environment to which the offspring is exposed during the developmental period can permanently program many aspects of its development. These programmed events are expressed

\footnotetext{
^ Corresponding author

e-mail: chinedum.emelike@funai.edu.ng
}

during adulthood as altered physiology or pathology; they include coronary artery disease, hypertension, adiposity, insulin resistance, metabolic syndrome and osteoporosis [1]. Hibiscus sabdariffa is a species of hibiscus, native to the old world tropics, the plant is grown in all parts of the world [2]. It is cultivated for the importance of the leaf, seed, fleshy calyx or fiber [3]. In Nigeria, the aqueous extract of calyx 
is use as refrigerant in the form of tea which is known as "Zobo", is commonly consumed by people of all ages [4]. Studies have shown that Hibiscus sabdariffa have been used in folk medicine in the treatment of several complaints, such as high blood pressure, liver diseases and fever. Other properties include antihyperlipidemic, antiseptic, aphrodisiac, astringent, cholagogue, demulcent, emollient, anticancer and antioxidant properties $[4,5]$.

A few studies in rats have shown that consumption of the extract of Hibiscus sabdariffa during pregnancy and lactation results in increased postnatal weight gain, delayed onset of puberty and elevated body mass index at onset of puberty, in female offspring [6-9]. Maternal and early life nutritional cues seem to "program" the developmental trajectory of a child by augmenting the timing of puberty onset for reproductive advantage in a predicted poor environment [10]. In Nigeria, the sweetened aqueous extract of Hibiscus sabdariffa is commonly consumed by both males and females, including pregnant and lactating mothers, not necessarily for medicinal purposes, but as a substitute for carbonated drinks, without regards to the physiological state of the body [11].

Hibiscus sabdariffa has been reported to have potential benefits in improving the iron status of women of childbearing age with time, and in protecting against stunting among toddlers during prolonged dry/lean season when prevalence of food and nutrition insecurity are highest [12]. Flavonoids are polyphenolic phytochemicals found in a variety of food items and beverages, and are characterized by different chemical structures and physiological properties $[13,14]$. The study of flavonoids, which are the most abundant phytochemical constituents of the highly consumed beverage, Hibiscus sabdariffa, is of great importance, since at high doses, the adverse effects of flavonoids may outweigh their beneficial ones. This present study, therefore, aimed to determine the effects of perinatal administration of flavonoid-rich extract from Hibiscus sabdariffa to feed-restricted rats, on offspring postnatal growth and reproductive development.

\section{MATERIALS AND METHOD}

\section{Plant materials}

Mature calyces of Hibiscus sabdariffa were purchased from a local market in Abakaliki, Ebonyi State. Mr. C. J. Onyeukwu, a taxonomist of the Plant Science \& Biotechnology Department of the University, authenticated the plant samples. A voucher specimen (UNH No.75a) of the plant was deposited at the herbarium.

\section{Preparation of extract}

The extraction procedure was according to the method of Iyare and Adegoke [11]. Briefly, $2000 \mathrm{~g}$ of the calyces powder were extracted by maceration in $5 \mathrm{~L}$ of methanol for $48 \mathrm{~h}$ with intermittent agitations. The powder was exhaustively extracted with repeated washings with fresh portions of methanol. The methanol extract was recovered after evaporation of the filtrate in vacuum at $40^{\circ} \mathrm{C}$ using a rotary evaporator. The concentrated extracts were transferred into sterile beakers covered with aluminium foil and stored in a refrigerator. The extracts were screened for the presence of different phytochemicals by employing the standard methods of Trease and Evans [15]. The constituents found in the extract include alkaloids, saponins, glycosides, flavonoids, phenols, tannins, steroids and reducing sugars. The flavonoid content was determined by applying the aluminum chloride method [16].

\section{Animal experiments}

Twenty five (25) mature inbred apparently healthy virgin female rats were procured from the Animal House, Department of Physiology, Alex Ekwueme Federal University Ndufu-Alike, Ebonyi State. They were acclimatized to their feed (Vital feed $\AA$, Nigeria) and water (which they had access to ad libitum) for two weeks before commencement of the experiment. The study protocol was approved by the Faculty of Basic Medical Research Ethics Committee of the Alex Ekwueme Federal University Ndufu-Alike, Ebonyi State. The study was carried out in accordance with the established institutional guidelines and the NIH guidelines on the use of experimental animals. The 70 percent feed-restricted diet was based on the individual dam average daily feed intake during the 7 days of acclimatization.

\section{Initiation of pregnancy}

The estrus cycles were monitored by examining the daily vaginal smears under light microscopy, and rats with two consecutive regular four-day estrus cycles were used for the study. At pro-estrus, male rats were introduced into female cages in the ratio of 1:2 to allow for mating. Mating was proved successful when spermatozoa were observed in the vaginal smear of the female rats the following morning and this was regarded as day 1 of pregnancy [17].

\section{Animal Grouping}

On day 1 of pregnancy, the twenty-five (25) rats were randomly placed into five groups of five rats per group (one animal per cage).

The Groups were as follows:

Group I (normal control): received only water and normal rat chow ad libitum.

Group II (feed-restricted control): received only water and $70 \%$ feed-restricted diet.

Group III (low dose flavonoid-rich extract of $\mathrm{Hs}$ ): $5 \mathrm{mg} / \mathrm{kg}$ body weight/day of flavonoid-rich extract of $H s+$ $70 \%$ feed-restricted diet.

Group IV (intermediate dose flavonoid-rich extract of $\boldsymbol{H s}$ ): $10 \mathrm{mg} / \mathrm{kg}$ body weight/day of flavonoid-rich extract of $H s+70 \%$ feed-restricted diet.

Group V (high dose flavonoid-rich extract of $\mathrm{Hs}$ ): $20 \mathrm{mg} / \mathrm{kg}$ body weight/day of flavonoid-rich extract of $H s$ $+70 \%$ feed-restricted diet.

The dams were housed individually throughout pregnancy (21 days) and lactation (21 days) and the administration was done orally using oropharyngeal cannula once per day for 42 days. On the day of delivery, each dam in each group was allowed 8 pups to nurse throughout the lactation period to eliminate the effect of under-nutrition or over-nutrition of the pups. The pups assumed the groups of their dams and after 21 days, the pups were weaned to tap water and feed ad libitum. After weaning, the female pups were housed in separate cages from the male pups. 


\section{Body weights and lengths}

Pups weights and lengths were recorded at birth, at weaning and at onset of puberty. Body mass index (BMI) was calculated accordingly using the formula.

$$
\mathrm{BMI}=\frac{\text { Weight }(\mathrm{g})}{\text { Length }(\mathrm{cm})^{2}}
$$

Observation of Vaginal Opening (VO) in females and Balano-preputial separation (BPS) in males

Since onset of puberty (puberty development) usually occurs not very long after weaning, from day 21 and above, the rats were observed daily for VO (females) and BPS (males). Age (in days) at onset of puberty was recorded.

\section{Hormonal profile analysis}

At onset of puberty, two male and two female pups were randomly selected from the pups from each group for hormone profile. Two (2) $\mathrm{ml}$ of blood samples were collected from the orbital route of each rat [18] into plain tubes for hormonal profile test. Serum levels of follicle stimulating hormone (FSH), luteinizing hormones (LH), estradiol and testosterone for female and male offspring were measured by enzyme linked immunosorbent assay (ELISA), using the protocols as described by the manufacturer's kit.

\section{Histological studies}

The rats were sacrificed by cervical dislocation. The ovaries and testes were excised following the abdominal incision and weighed. They were cleaned of any adherent tissues and preserved in Bouin's fluid for routine histological processing and subsequent histopathological examination. Subsequently, 15-micron thick paraffin sections was prepared, stained with hematoxylin and eosin and examined microscopically for the histopathological studies.

\section{Statistical analysis}

Results were analyzed using GraphPad Prism (GraphPad $\AA$ Software, San Diego, CA, USA). One-way ANOVA, followed by Turkey post hoc test, was used for data comparison, and values were regarded significant at $p<0.05$. Results were expressed as mean \pm standard error of the mean (SEM).

\section{RESULTS}

Table 1 shows the anthropometric indices of perinatal administration of flavonoid-rich extract from Hibiscus sabdariffa to feed-restricted rats on offspring at birth. There was a significant $(\mathrm{p}<0.05)$ increase in both birth weight and length in Group III, Group IV and Group V when compared with Group I and Group II. Group V had significant $(p<0.05)$ increase in BMI as compared with Group I and Group II, while Group IV and III also had significant $(p<0.05)$ increase in BMI when compared with Group I only.

Table 2 shows the effects of perinatal administration of flavonoid-rich extract from Hibiscus sabdariffa to feedrestricted rats on offspring body parameters at weaning (day 21). Group III, Group IV and Group V had significant $(\mathrm{p}<0.05)$ increase in both weight and length at weaning (day 21), when compared with Group I and Group II. Group V had significant $(\mathrm{p}<0.05)$ increase in BMI, when compared with Group I and Group II, while Group III had significant $(p<0.05)$ decrease in BMI, when compared with Group II only - as shown in Table 2.

Table 1. Effect of perinatal administration of flavonoid-rich extract from Hibiscus sabdariffa to feed-restricted rats on offspring body parameters at birth

\begin{tabular}{|l|c|c|c|}
\hline \multicolumn{1}{|c|}{ Groups } & Weight $(\mathrm{g})$ & Length $(\mathrm{cm})$ & BMI $\left(\mathrm{g} / \mathrm{cm}^{2}\right)$ \\
\hline Group I & $4.02 \pm 0.12$ & $4.1 \pm 0.04$ & $0.24 \pm 0.002$ \\
\hline Group II & $4.64 \pm 0.08^{\mathrm{a}}$ & $4.1 \pm 0.02$ & $0.28 \pm 0.006^{\mathrm{a}}$ \\
\hline Group III & $5.86 \pm 0.10^{\mathrm{ab}}$ & $4.5 \pm 0.02^{\mathrm{ab}}$ & $0.29 \pm 0.006^{\mathrm{a}}$ \\
\hline Group IV & $6.10 \pm 0.07^{\mathrm{ab}}$ & $4.5 \pm 0.03^{\mathrm{ab}}$ & $0.30 \pm 0.009^{\mathrm{a}}$ \\
\hline Group V & $6.36 \pm 0.11^{\mathrm{ab}}$ & $4.5 \pm 0.02^{\mathrm{ab}}$ & $0.31 \pm 0.007^{\mathrm{ab}}$ \\
\hline
\end{tabular}

Values are mean \pm standard error of mean. $a-p<0.05$ versus normal control (Group I); b - $p<0.05$ versus feed-restricted control (Group II)

Table 2. Effects of perinatal administration of flavonoid-rich extract from Hibiscus sabdariffa to feed-restricted rats on offspring body parameters at weaning (day 21)

\begin{tabular}{|l|c|c|c|}
\hline \multicolumn{1}{|c|}{ Groups } & Weight $(\mathrm{g})$ & Length $(\mathrm{cm})$ & BMI $\left(\mathrm{g} / \mathrm{cm}^{2}\right)$ \\
\hline Group I & $23.88 \pm 0.37$ & $9.3 \pm 0.03$ & $0.28 \pm 0.005$ \\
\hline Group II & $26.20 \pm 0.27^{\mathrm{a}}$ & $9.4 \pm 0.03$ & $0.29 \pm 0.002$ \\
\hline Group III & $28.22 \pm 0.38^{\mathrm{ab}}$ & $10.2 \pm 0.02^{\mathrm{ab}}$ & $0.27 \pm 0.003^{\mathrm{b}}$ \\
\hline Group IV & $30.10 \pm 0.23^{\mathrm{ab}}$ & $10.2 \pm 0.02^{\mathrm{ab}}$ & $0.29 \pm 0.004$ \\
\hline Group V & $33.46 \pm 0.68^{\mathrm{ab}}$ & $10.3 \pm 0.04^{\mathrm{ab}}$ & $0.31 \pm 0.004^{\mathrm{ab}}$ \\
\hline
\end{tabular}

Values are mean \pm standard error of mean. $a-p<0.05$ versus normal control (Group I); $b-p<0.05$ versus feed-restricted control (Group II)

Data presented in Table 3 shows that Group III, Group IV and Group V had significant $(\mathrm{p}<0.05)$ increase in weight, length and age at onset of puberty, when compared with Group I and Group II, while Group II had significant $(p<0.05)$ increase in weight and age, when compared with Group I only. Furthermore, there were significant increases in BMI of Group IV and Group V rats, when compared to Group I and Group II.

Table 3. Effects of perinatal administration of flavonoid-rich extract from Hibiscus sabdariffa to feed-restricted rats on offspring body parameters and age at onset of puberty

\begin{tabular}{|l|c|c|c|c|}
\hline \multicolumn{1}{|c|}{ Groups } & Weight $(\mathrm{g})$ & Length $(\mathrm{cm})$ & $\mathrm{BMI}\left(\mathrm{g} / \mathrm{cm}^{2}\right)$ & Age (days) \\
\hline Group I & $44.52 \pm 0.37$ & $13.4 \pm 0.04$ & $0.25 \pm 0.003$ & $36.40 \pm 0.24$ \\
\hline Group II & $47.80 \pm 0.45^{\mathrm{a}}$ & $13.5 \pm 0.03$ & $0.26 \pm 0.002$ & $37.60 \pm 0.24^{\mathrm{a}}$ \\
\hline Group III & $54.50 \pm 0.54^{\mathrm{ab}}$ & $14.3 \pm 0.04^{\mathrm{ab}}$ & $0.26 \pm 0.002$ & $39.20 \pm 0.37^{\mathrm{ab}}$ \\
\hline Group IV & $59.66 \pm 0.63^{\mathrm{ab}}$ & $14.5 \pm 0.04^{\mathrm{ab}}$ & $0.28 \pm 0.002^{\mathrm{ab}}$ & $39.80 \pm 0.20^{\mathrm{ab}}$ \\
\hline Group V & $72.08 \pm 1.02^{\mathrm{ab}}$ & $14.6 \pm 0.02^{\mathrm{ab}}$ & $0.34 \pm 0.004^{\mathrm{ab}}$ & $41.60 \pm 0.24^{\mathrm{ab}}$ \\
\hline
\end{tabular}
Values are mean \pm standard error of mean; $a-p<0.05$ versus normal
control (Group I) $; b-p<0.05$ versus feed-restricted control (Group II)

As shown in Table 4, there were no significant differences ( $p>0.05)$ in testosterone, follicle stimulating hormone (FSH), luteinizing hormone ( $\mathrm{LH})$ and estradiol levels at onset of puberty of the rats in the groups, respectively.

The effect of perinatal administration of flavonoid-rich extract from Hibiscus sabdariffa to feed-restricted rats on offspring relative and absolute organ weight of testes is shown in Table 5. As revealed in the Table, Group III, Group IV and Group V had significant $(p<0.05)$ increase in absolute organ weight and relative weight of testes, on comparison with Group I and Group II. 
Effect of perinatal administration of flavonoid-rich extract from Hibiscus sabdariffa to feed-restricted rats, ...

Table 4. Effects of perinatal administration of flavonoid-rich extract from Hibiscus sabdariffa to feed-restricted rats on some reproductive hormone levels of offspring at onset of puberty

\begin{tabular}{|l|c|c|c|c|}
\hline \multicolumn{1}{|c|}{ Groups } & $\begin{array}{c}\text { Testosterone } \\
(\mathrm{ng} / \mathrm{ml})\end{array}$ & $\begin{array}{c}\mathrm{FSH} \\
(\mathrm{mIU} / \mathrm{ml})\end{array}$ & $\begin{array}{c}\mathrm{LH} \\
(\mathrm{mIU} / \mathrm{ml})\end{array}$ & $\begin{array}{c}\text { Estradiol } \\
(\mathrm{Pg} / \mathrm{ml})\end{array}$ \\
\hline Group I & $1.085 \pm 0.032$ & $2.533 \pm 0.196$ & $3.095 \pm 0.967$ & $134.60 \pm 13.18$ \\
\hline Group II & $1.018 \pm 0.049$ & $2.458 \pm 0.191$ & $3.003 \pm 0.063$ & $127.70 \pm 10.11$ \\
\hline Group III & $0.988 \pm 0.029$ & $2.453 \pm 0.188$ & $2.963 \pm 0.064$ & $127.80 \pm 9.46$ \\
\hline Group IV & $0.973 \pm 0.065$ & $2.425 \pm 0.208$ & $2.985 \pm 0.119$ & $127.30 \pm 10.99$ \\
\hline Group V & $0.943 \pm 0.028$ & $2.375 \pm 0.178$ & $3.008 \pm 0.083$ & $119.30 \pm 6.75$ \\
\hline \multicolumn{5}{|l}{ Values are mean \pm standard error of mean }
\end{tabular}

Table 5. Effect of perinatal administration of flavonoid-rich extract from Hibiscus sabdariffa to feed-restricted rats on offspring relative and absolute organ weight of testes

\begin{tabular}{|l|c|c|}
\hline \multicolumn{1}{|c|}{ Groups } & Absolute Weight $(\mathrm{g})$ & Relative Weight $(\mathrm{G})$ \\
\hline Group I & $0.23 \pm 0.00$ & $0.0050 \pm 0.0000$ \\
\hline Group II & $0.26 \pm 0.01$ & $0.0053 \pm 0.0003$ \\
\hline Group III & $0.32 \pm 0.01^{\mathrm{ab}}$ & $0.0058 \pm 0.0003^{\mathrm{a}}$ \\
\hline Group IV & $0.37 \pm 0.01^{\mathrm{ab}}$ & $0.0063 \pm 0.0003^{\mathrm{a}}$ \\
\hline Group V & $0.39 \pm 0.00^{\mathrm{ab}}$ & $0.0058 \pm 0.0003^{\mathrm{a}}$ \\
\hline \multicolumn{2}{|c|}{ Values are mean \pm standard error of mean. ${ }^{\mathrm{a}}=\mathrm{p}<0.05$ versus normal control } \\
\hline
\end{tabular}

(Group I); ${ }^{b}=p<0.05$ versus feed-restricted control (Group II)

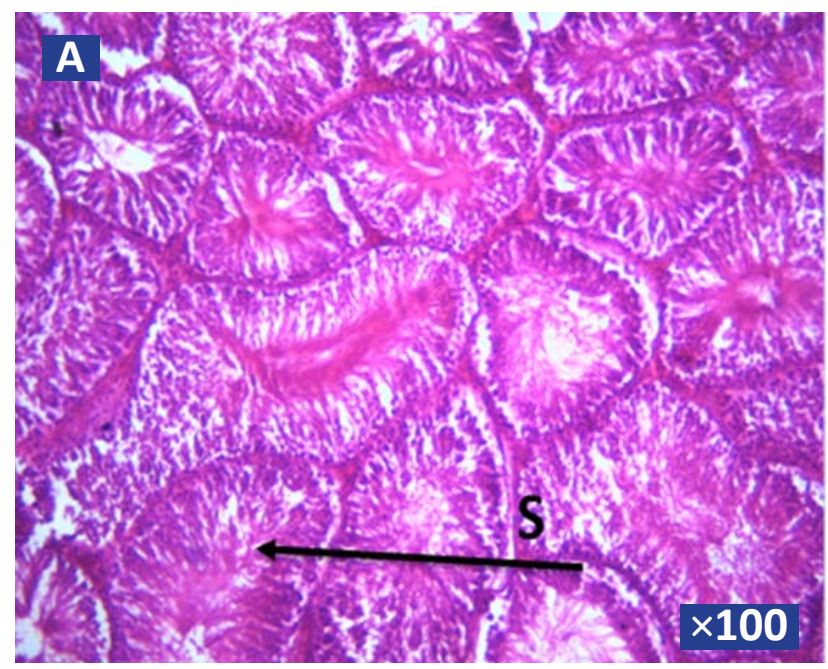

Table 6 shows the effect of perinatal administration of flavonoid-rich extract from Hibiscus sabdariffa to feedrestricted rats on offspring absolute and relative organ weight of ovaries. Group III, Group IV and Group V had significant increase in absolute organ weight of the ovaries, when compared with Group I and Group II. The relative weight of ovaries of Group IV and V had significant increase, when compared with Group I only.

Table 6. Effects of perinatal administration of flavonoid-rich extract from Hibiscus sabdariffa to feed-restricted rats on offspring absolute and relative organ weight of ovaries

\begin{tabular}{|l|c|c|}
\hline \multicolumn{1}{|c|}{ Groups } & Absolute Weight $(\mathrm{g})$ & Relative Weight $(\mathrm{g})$ \\
\hline Group I & $0.019 \pm 0.000$ & $0.0004 \pm 0.0000$ \\
\hline Group II & $0.021 \pm 0.000^{\mathrm{a}}$ & $0.0005 \pm 0.0000$ \\
\hline Group III & $0.026 \pm 0.002^{\mathrm{ab}}$ & $0.0005 \pm 0.0000$ \\
\hline Group IV & $0.034 \pm 0.001^{\mathrm{ab}}$ & $0.0006 \pm 0.0000^{\mathrm{a}}$ \\
\hline Group V & $0.042 \pm 0.00^{\mathrm{ab}}$ & $0.0006 \pm 0.0000^{\mathrm{a}}$ \\
\hline
\end{tabular}

Values are mean \pm standard error of mean. ${ }^{a}=p<0.05$ versus normal control (Group I); ${ }^{b}=p<0.05$ versus feed-restricted control (Group II)

Figure 1 (A-B). Photomicrograph of Group I section of testis $(\times 100 / 400)(H / E)$ showing normal testicular architecture with numerous seminiferous tubule that are lined with interstitial cells of the leydig (ICL) and sertoli cell (SC) with well-enhanced spermatogenesis (WES). The overall features appear normal
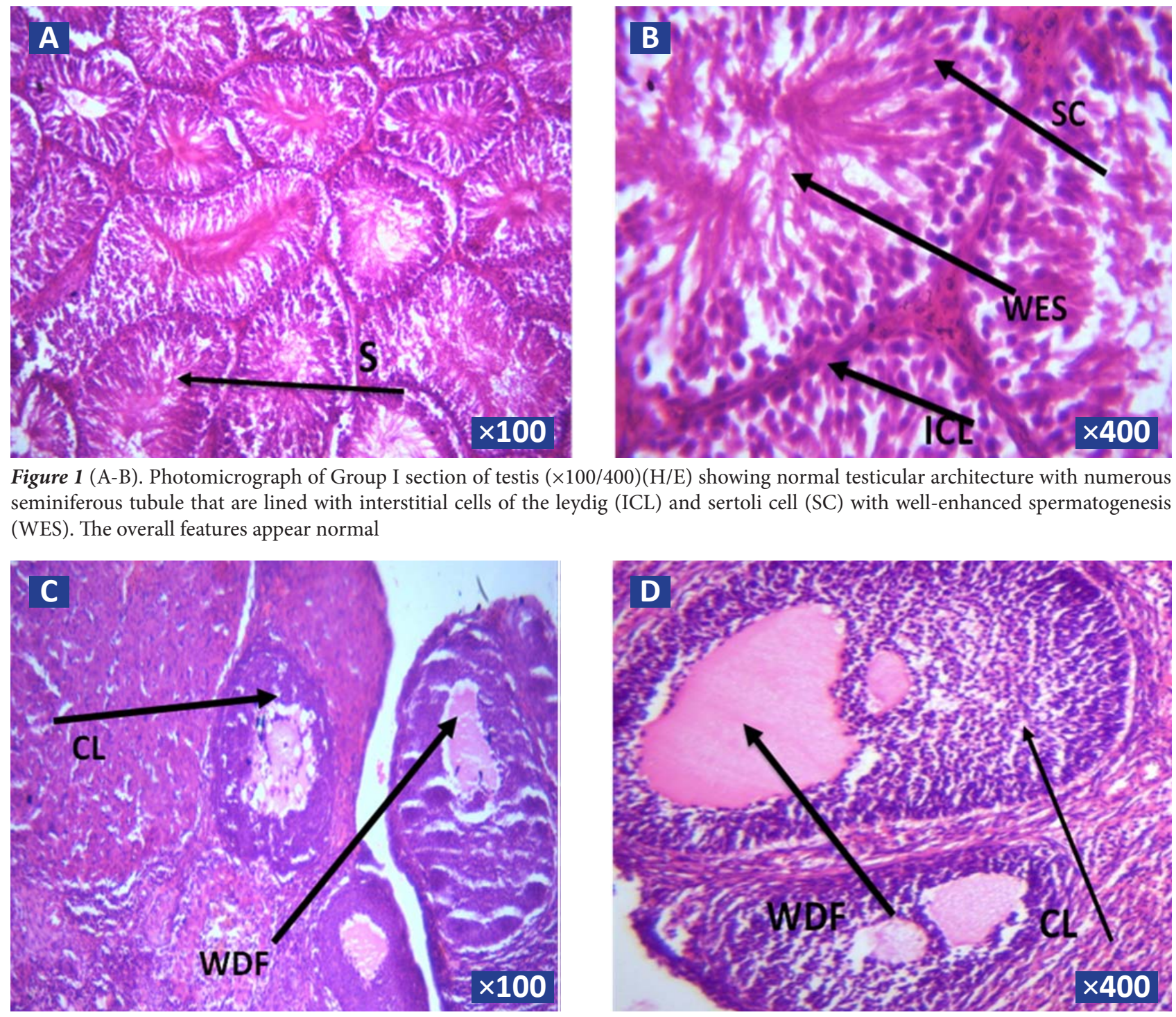

Figure $2(\mathrm{C}-\mathrm{D})$. Photomicrograph of Group I section of ovary $(\times 100 / 400)(\mathrm{H} / \mathrm{E})$ revealing normal ovarian tissue with large corpus luteum $(\mathrm{CL})$ and well developing follicles (DF) 

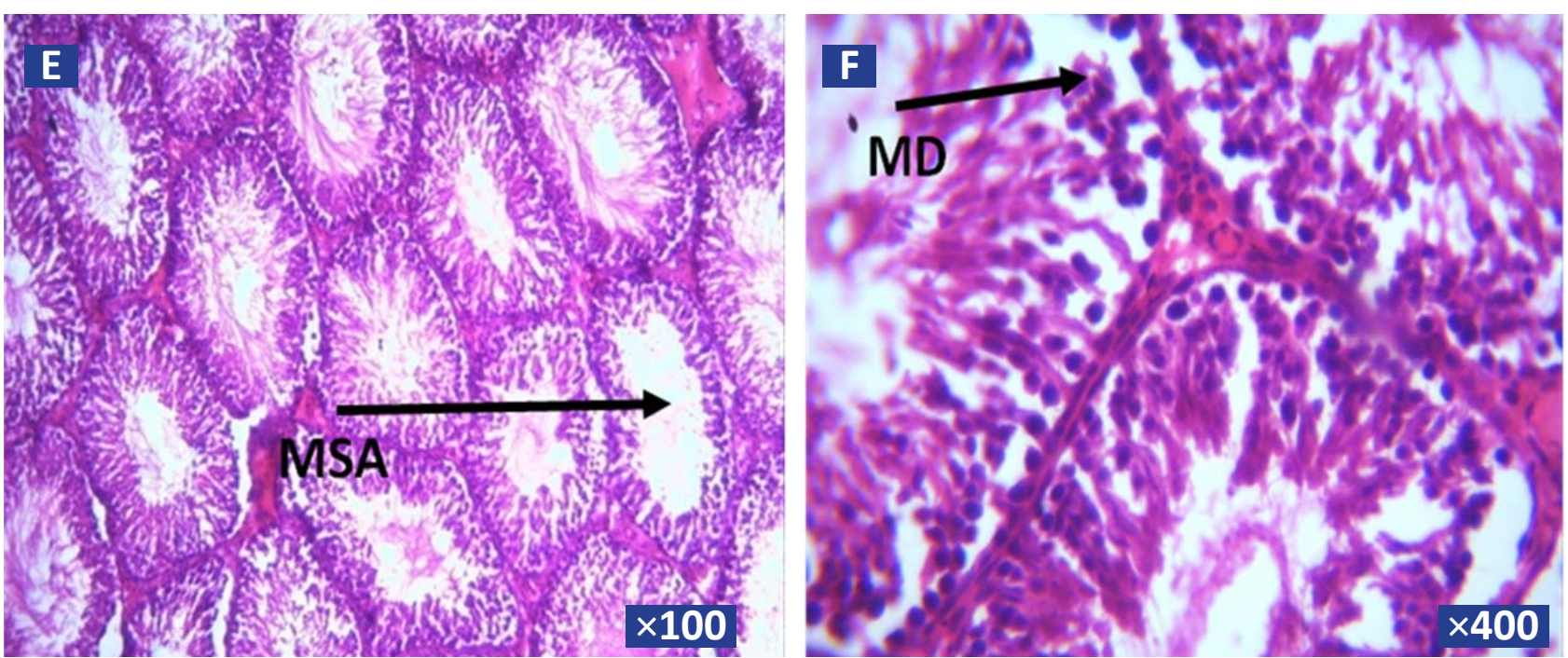

Figure 3 (E-F). Photomicrograph of Group II section of testes $(\times 100 / 400)(H / E)$ showing mild arrest of spermatogenesis (MAS) and mild distortion (MD) of the interstitial cells of the leydig, otherwise - normal
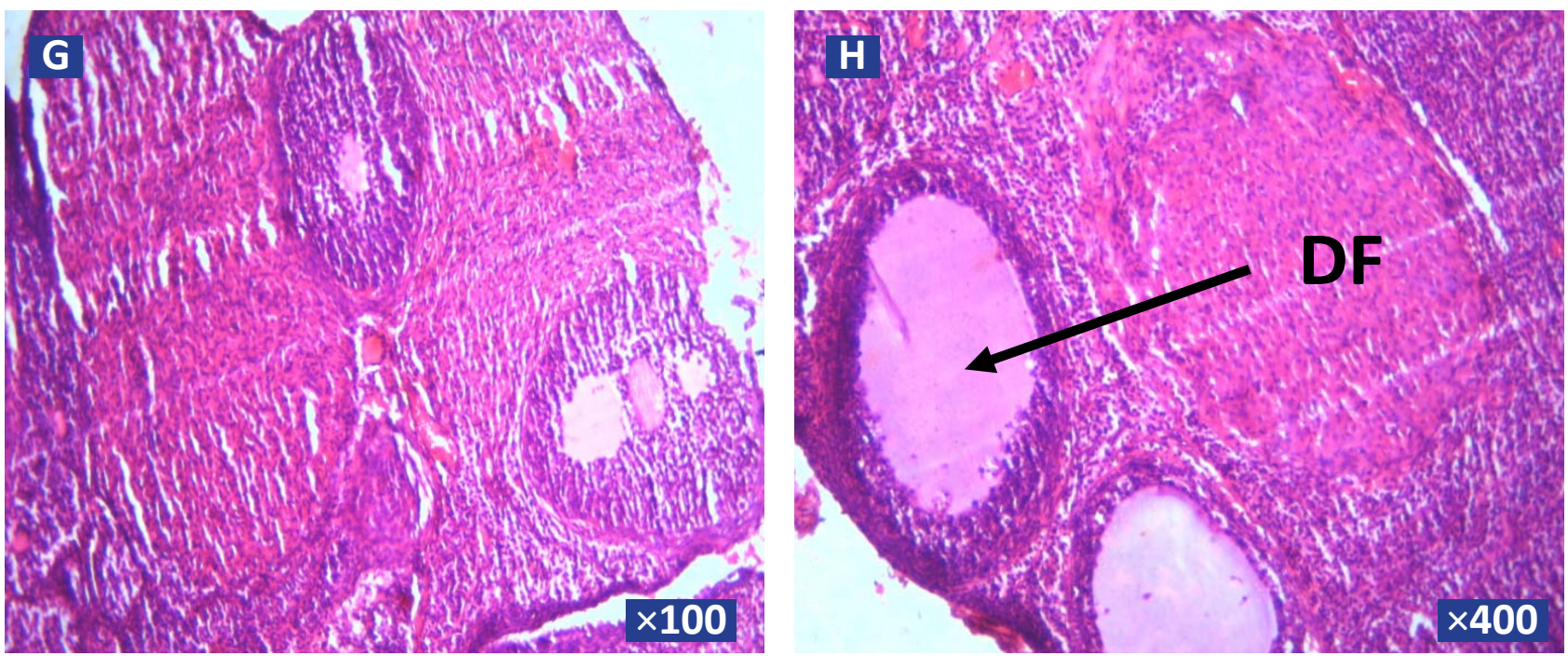

Figure $4(\mathrm{G}-\mathrm{H})$. Photomicrograph of Group II section of ovary $(\times 100 / 400)(\mathrm{H} / \mathrm{E})$ illustrating ovarian tissue with corpus luteum (CL) and increased, well-developing follicles (DF)
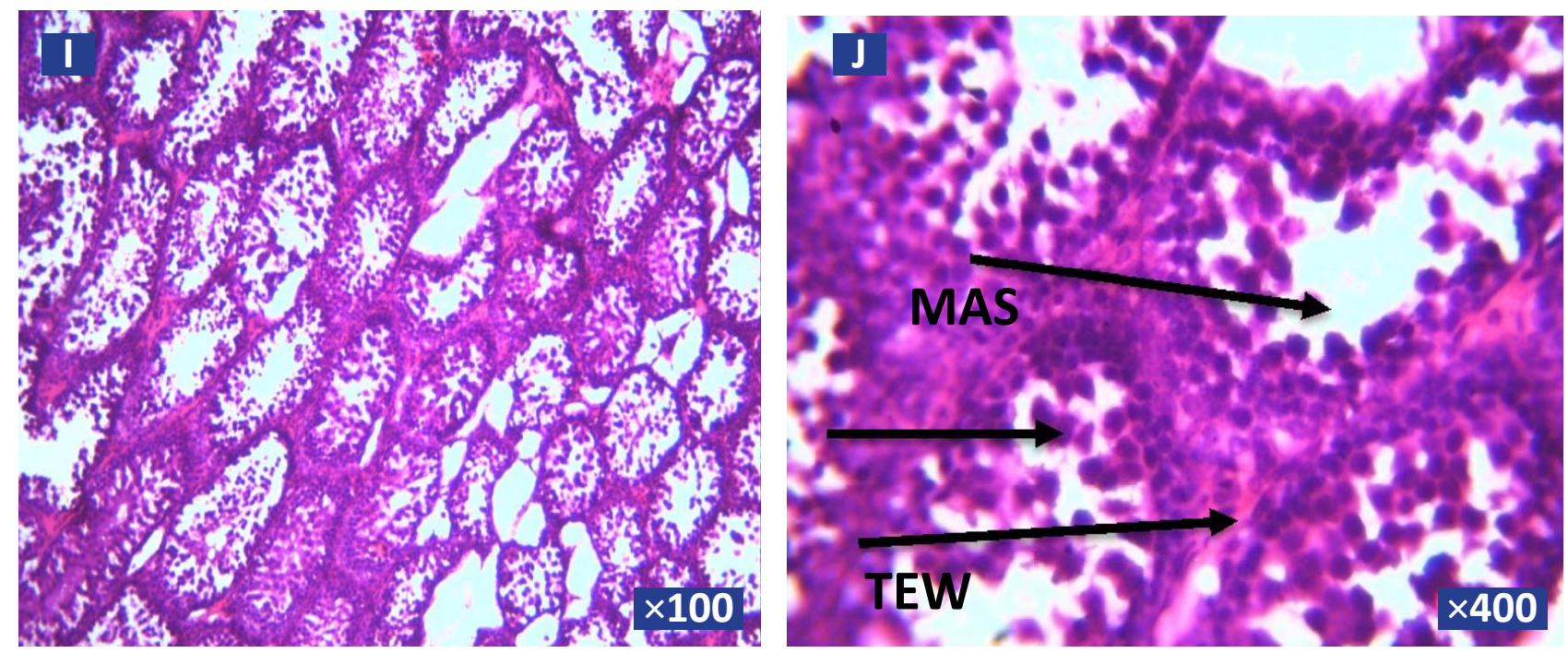

Figure 5 (I-J): Photomicrograph of Group III section of testes $(\times 100 / 400)(\mathrm{H} / \mathrm{E})$ demonstrating moderate degeneration of the testicular tissue with moderate arrest of spermatogenesis (MAS), centrally located sertoli cells (SC) that have irregular outline within the seminiferous tubules and thickened epithelia wall (TEW) of the seminiferous tubules 

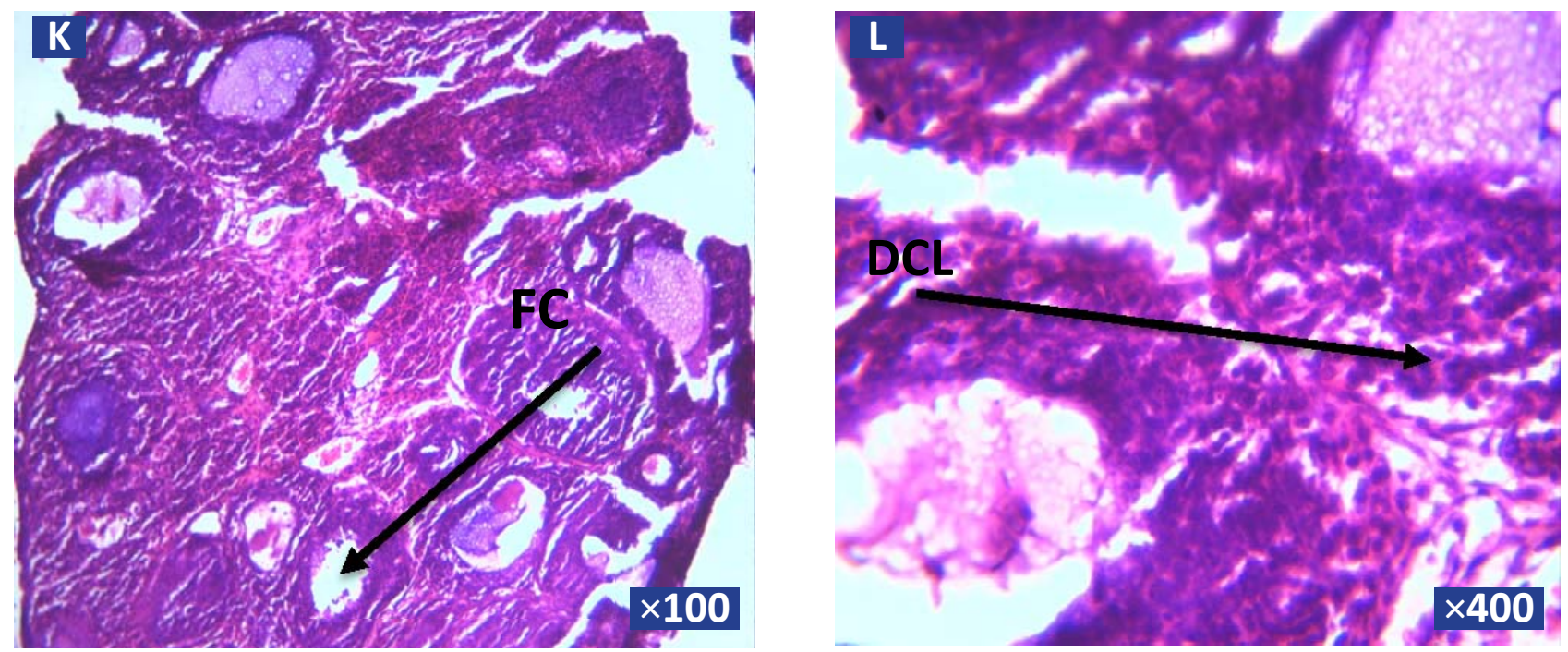

Figure $6(\mathrm{~K}-\mathrm{L})$. Photomicrograph of Group III section of ovary $(\times 100 / 400)(\mathrm{H} / \mathrm{E})$ showing moderate effect on the ovarian tissue with mild disintegration of Corpus Luteum (DCL) and moderate formation of Follicular Cyst (FC).
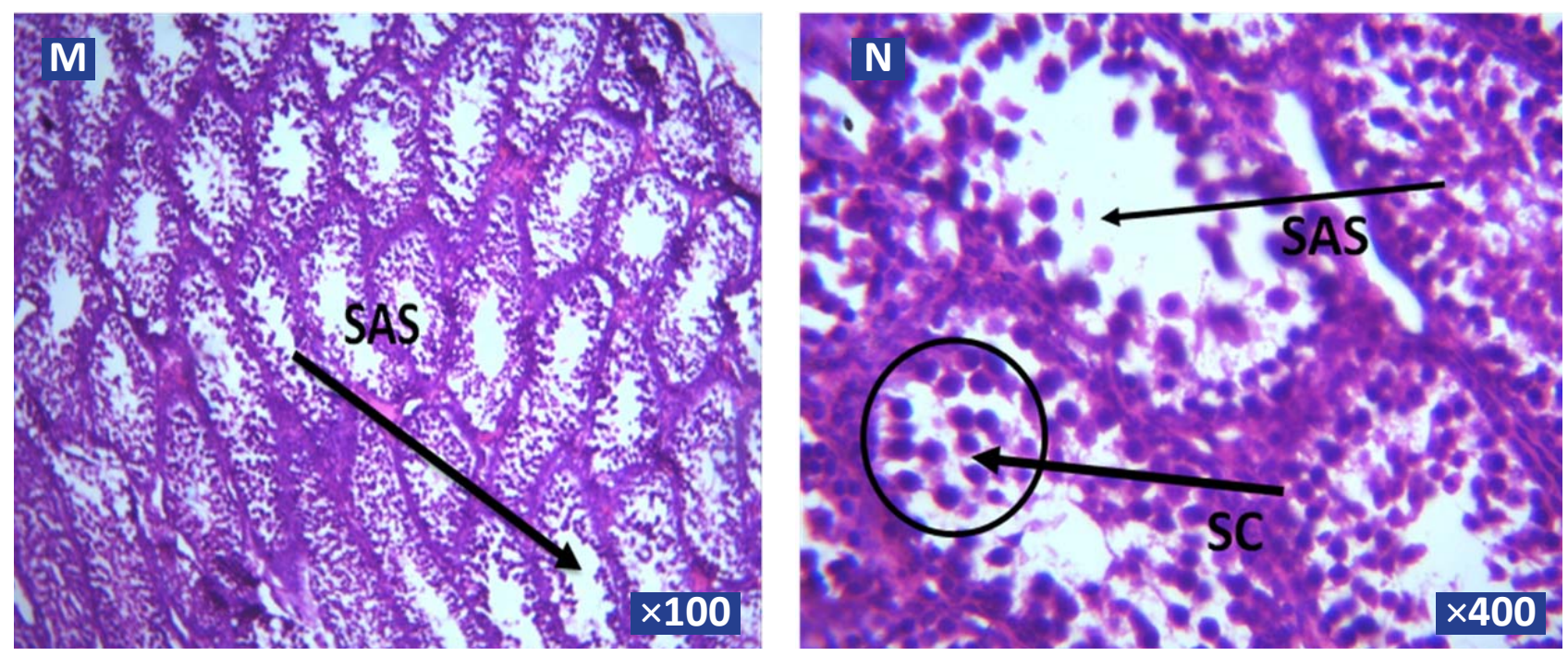

Figure $7(\mathrm{M}-\mathrm{N})$. Photomicrograph of Group IV section of testis $(\times 100 / 400)(\mathrm{H} / \mathrm{E})$ indicating moderate to severe degeneration of the testicular tissue with Severe Arrest of Spermatogenesis (SAS). Moreover, the seminiferous tubules are lined extensively by Sertoli Cell (SC) (sertoli cell syndrome)
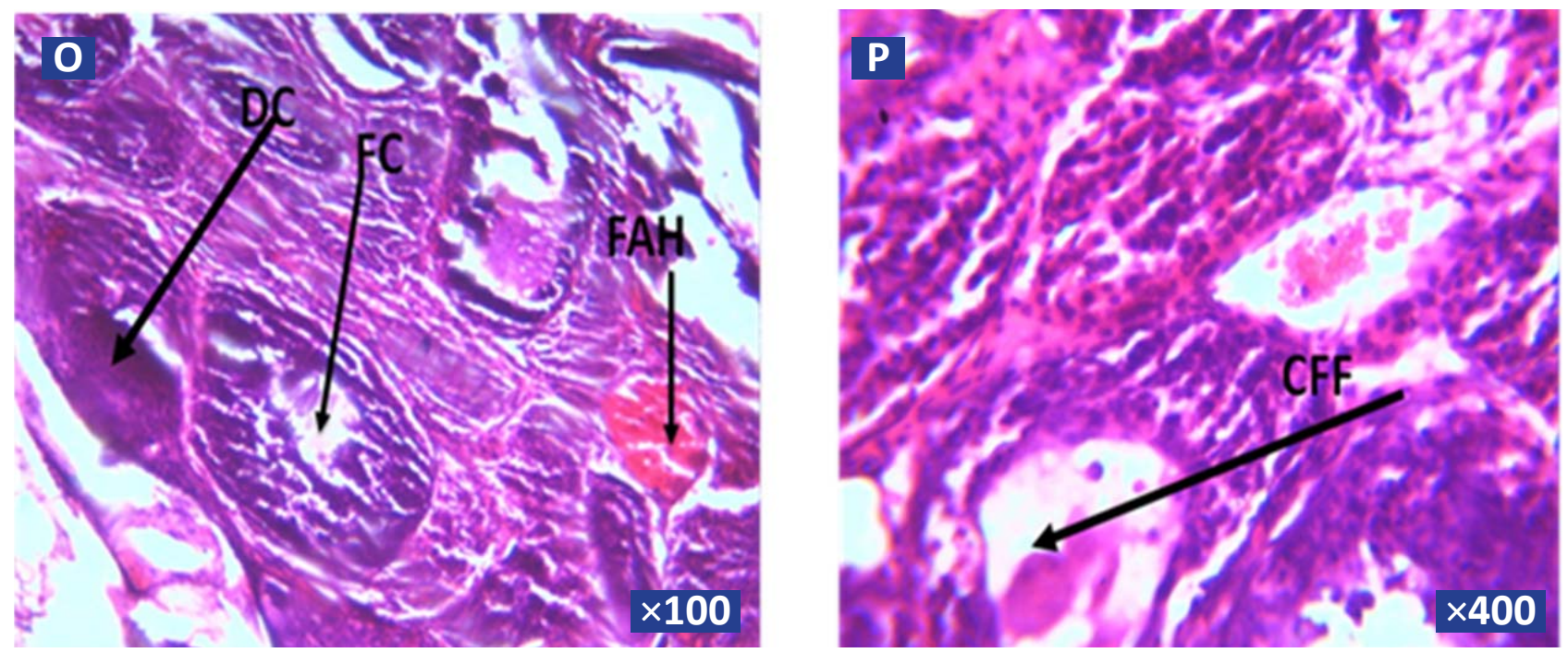

Figure 8 (O-P). Photomicrograph of Group IV section of ovary $(\times 100 / 400)(\mathrm{H} / \mathrm{E})$ showing moderate to severe effect on the ovarian tissue, with severe degeneration of corpus luteum (DCL), clearing of the follicular fluids (CFF), focal area hemorrhage (FAH) and moderate formation of follicular cyst (FC) 

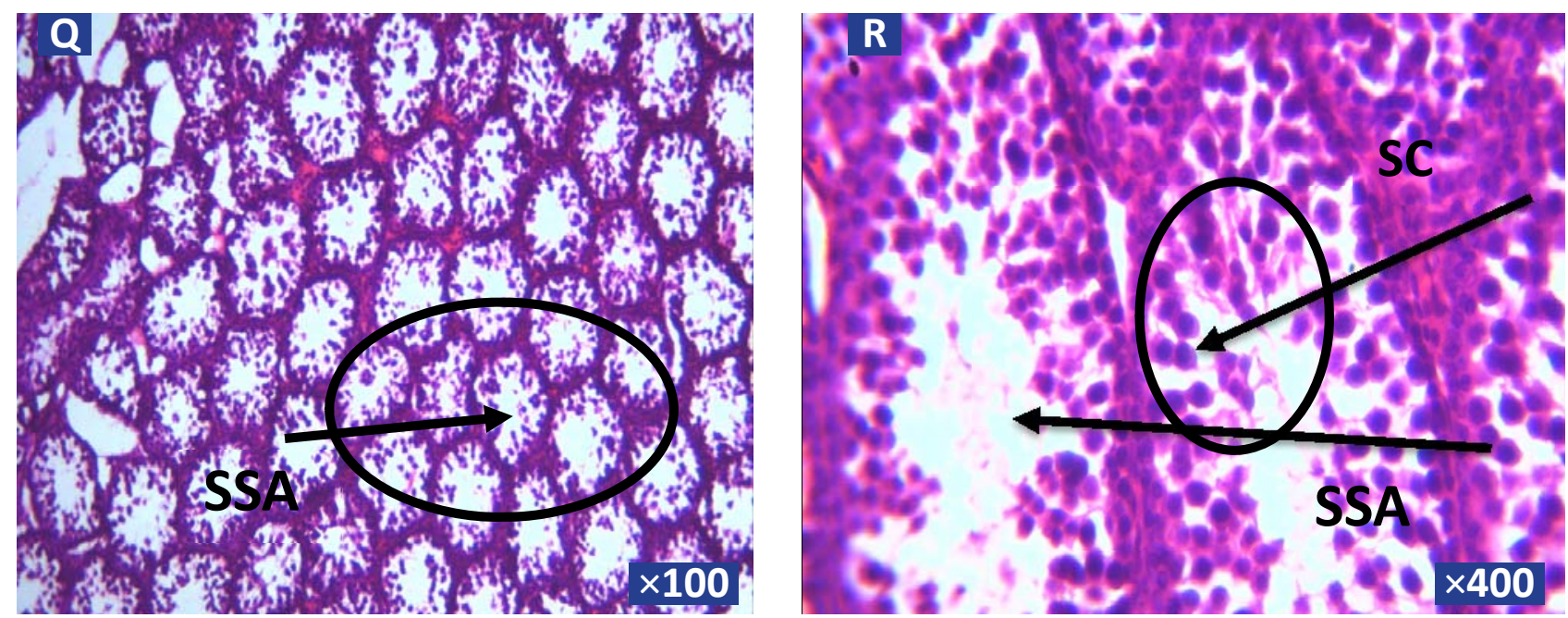

Figure $9(\mathrm{Q}-\mathrm{R})$. Photomicrograph of Group V section of testes $(\times 100 / 400)(\mathrm{H} / \mathrm{E})$ revealing severe degeneration of the testicular tissue, with severe spermatogenic arrest (SSA) at the spermatid stage, while the seminiferous tubules are lined severely by sertoli cell (SC)
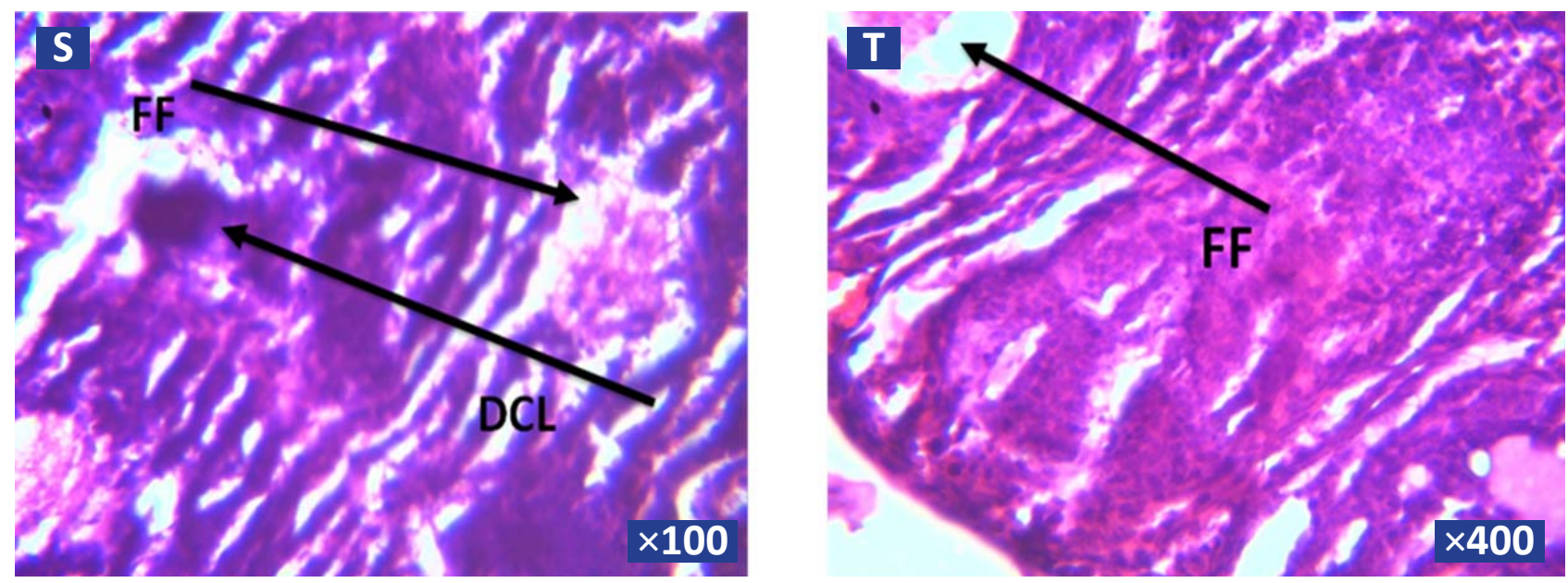

Figure 10 (S-T). Photomicrograph of Group V section ovary $(\mathrm{x} 100 / 400)(\mathrm{H} / \mathrm{E})$ showing moderate to severe effect on the ovarian tissue and severe degeneration of corpus luteum (DCL) and poor formation follicular fluid (FF)

\section{DISCUSSION}

Programming is the process whereby a spur or insult acting during critical periods of growth and development might permanently alter tissue structure and function to produce adverse effects in adult life [1]. The present study indicates that offspring of rats that consumed flavonoids from Hs extract during antenatal and postnatal (Hs dams) had significant $(p<0.05)$ increase in birth weight and length of the offspring. The increase in body weight could be attributed to the following: the developing foetuses of the Hs dams might have mustered adaptive mechanisms to safeguard their growth and development $[19,20]$, and/or the malnutrition in the Hs dams that started early in pregnancy may have prompted placental development that may have favoured elevated nutrient delivery to the growing foetuses [21-23], lastly, the flavonoid constituent of Hs might have directly influenced the growth of the foetuses, as flavonoids have demonstrated direct growth promoting effect [24]. Moreover, the flavonoids in the Hs extract could have inhibited the activity of $11 \beta$-hydroxysteroid dehydrogenase type 2 (11ßHSD-2) [25-27]. This greatly reduces the conversion of the active glucocorticoid to the inactive form and thus increases the level of glucocorticoid reaching the foetus.
Elevated concentrations of glucocorticoids beyond physiological levels have been shown to inhibit tissue accretion $[28,29]$ so well as to have major effects on the differentiation of a wide range of tissues, including the lungs, liver, kidneys, muscle, fat and gut [30]. They stimulate morphological and functional changes in these tissues and activate many of the biochemical processes that have little or no function in utero, but which are essential for survival post-natally [30]. Therefore, glucocorticoids signal adverse intrauterine conditions and adapt foetal development to ensure the maximum chances of survival both in utero and at birth. Of note: glucocorticoids have been shown to inhibit transplacental leptin flux [31-33].

Balano-preputial separation (BPS) in the male rat and Vagina opening in the female rat is considered a good marker of the onset of puberty [8]. In this present study, there was a delayed onset of puberty. In addition, the levels of testosterone, $\mathrm{FSH}, \mathrm{LH}$, and estradiol in the offspring of the $H_{s}$ dams at the time of puberty decreased (in a dose dependent manner), though not significantly $(p<0.05)$. The delayed onset of puberty in the offspring of the $H s$ dams could be through mechanisms that may be connected with elevated 
plasma glucocorticoid levels, which have been shown to cause a permanent resetting of endocrine systems, such as the somatotrophic and hypothalamo-pituitary adrenal axes [34-39].

The study revealed an increase in relative organ weight of testes and ovaries in the offspring of the $H s$ dams, (in a dose dependent manner). Organ weight is the most sensitive indicator of the effect of drug toxicity and is considered to be trustworthy [40]. However, significant changes in organ weights between treated and control animals could occur in the absence of any morphological changes or may forego morphological changes [40]. In this study, the increased relative weights of the testes and ovaries of the rats further affirm the distortion in the histological arrangement of the rats.

It is possible also, that the delayed puberty, decrease in the levels of testosterone, FSH, LH, and estradiol, increased relative weights and distortion in the histological arrangement of the testes and ovaries observed in the offspring of the $H s$ dams may also be due to the poor development of the hypothalamic neurocircuitry that controls energy homeostasis and reproductive functions that normally mature during lactation.

\section{CONCLUSION}

The study has shown that in the offspring of the $H s$ dams who were at no time during their development directly given flavonoid from $H s$, their accelerated postnatal growth and delayed puberty may have been due to overexposure to this substance during pregnancy and lactation.

\section{ORCID iDs}

Chinedum U. Emelike (Dhttps://orcid.org/0000-0002-2201-9795 Eghosa E. Iyare (1) https://orcid.org/0000-0002-3678-3524

\section{REFERNCES}

1. Godfrey KM, Gluckman PD, Hanson MA. Developmental origins of metabolic disease: life course and intergenerational perspectives. Trends Endocrinol Metab. 2010;21(4):199-205.

2. Chau JW, Jin MW, Wea LL, Chia YC, Fen PC, Tsui HT. Protective effect of Hibiscus anthocyannins against tertbutylhydroperoxideinduced hepatic toxicity in rats. Food Chem Toxicol. 2000;38(15): 412-7.

3. Dalziel JA, Ibrahim D. Nutrient composition and antimicrobial activity of sorrel drinks (zoborodo). J Med Food. 1973;7(3):370-8.

4. Emelike CU, Dapper DV. Effects of oral administration of aqueous extract of Hibiscus sabdariffa on some haematological parameters of wistar albino rats. IOSR-JDMS. 2013;9(1):31-4.

5. Ali BH, Wabel NA, Blunden G. Phytochemical, pharmacological and toxicological aspects of Hibiscus sabdariffa L: a review. Phytother Res. 2005;19(5):369-75.

6. Iyare EE, Adegoke OA. Maternal consumption of an aqueous extract of Hibiscus sabdariffa during lactation accelerates postnatal weight and delays onset of puberty in female offspring. Niger J Physiol Sci. 2008;23(1-2):89-94.

7. Iyare EE, Adegoke OA. Mechanism of the delayed puberty onset in offspring of rats that consumed aqueous extract of Hibiscus sabdariffa during pregnancy. Niger J Physiol Sci. 2008;23(1-2):71-7.

8. Iyare EE, Adegoke OA. Postnatal weight gain and onset of puberty in rats exposed to aqueous extract of Hibiscus sabdariffa in utero. Pak J Nutr. 2008;7(1):98-101.
9. Iyare EE, Nwagha UI. Delayed puberty onset in rats that consumed aqueous extract of Hibiscus sabdariffa during the juvenile-pubertal period. PJBS. 2009;12(23):1505-10.

10. Barker DJ, Clark PM. Fetal undernutrition and disease in later life. Rev Reprod. 1997;2:105-12.

11. Iyare EE, Adegoke OA. Gestational outcome in rats that consumed aqueous extract of Hibiscus Sabdariffa during pregnancy. Pak J Nutr. 2011;10(4):350-4.

12. Kubuga CK, Hong HG, Song WO. Hibiscus sabdariffa meal improves iron status of childbearing age women and prevents stunting in their toddlers in Northern Ghana. Nutrients. 2019;11(1):198.

13. Beecher GR. Overview of dietary flavonoids: nomenclature, occurrence and intake. J Nutr. 2003;133(10):3248S-3254S.

14. Erdman JW. Flavonoids and heart health: proceedings of the ILSI North America flavonoids workshop, Washington DC. J Nutr. 2007;137(1):718S-737S.

15. Trease GE, Evans WC. Pharmacognosy. 15th Ed. London: Saunders Publishers; 2002:42-44, 221-229, 246-249, 304-306, 331-332, 391-393.

16. Formagio ASN, Ramos DD, Vieira MC, Ramalho SR, Silva MM, Zárate NAH, et al. Phenolic compounds of Hibiscus sabdariffa and influence of organic residues on its antioxidant and antitumoral properties. Braz J Biol. 2015;75(1):69-76.

17. Mallie JP. Boudzoumou P. Functional Renal maturation in rats' neonates after prenatal exposure to furoemide. Pediatr Nephrol. 1996;10:458-60.

18. Parasuraman S, Raveendran R, Kesavan R. Blood sample collection in small laboratory animals. J Pharmacol Pharmacother. 2010;1:87-93.

19. Gluckman PD, Hanson MA. Developmental origins of disease paradigm: a mechanistic and evolutionary perspective. Pediatric Res. 2004;56:311-7.

20. Gluckman PD, Hanson MA. The developmental origins of the metabolic syndrome. Trends Endocrinol Metab. 2004;15:183-7.

21. Woodall SM, Breier BH, Johnston BM, Gluckman PD. A model of intrauterine growth retardation caused by chronic maternal undernutrition in the rat: effects on the somatotrophic axis and postnatal growth. J Endocrinol. 1996;150:231-42.

22. Osgerby JC, Wathes DC, Howard D, Gadd TS. The effect of maternal undernutrition on ovine fetal growth. J Endocrinol. 2002;173:131-41.

23. Fowden AL, Ward JW, Wooding FPB, Forhead AJ, Constanci M. Programming placental nutrient transport capacity. J Physiol. 2006;572:5-15.

24. Hilakivi-Klarke L, Chow E, Clarke R. Maternal genistein exposure mimics the effects of estrogen on mammary gland development in female mouse offspring. Oncol Rep. 1998;5(3):609616.

25. Lee YS, Lorenzo BJ, Koufis T, Reidenberg MM. Grapefruit juice and its flavonoids inhibit 11 beta-hydroxysteroid dehydrogenase. Clin Pharmacol Ther. 1996;59(1):62-71.

26. Zhang YD, Wang MS. Inhibition of 11 betahydroxysteroid dehydrogenase obtained from guinea pig kidney by some bioflavonoids and triterpenoids. Zhongguo Yao Li Xue Bao. 1997;8(3):240-4.

27. Guo J, Reidenberg MM. Inhibition of 11 beta-hydroxysteroid dehydrogenase by bioflavonoids and their interaction with furosemide and gossypol. J Lab Clin Med. 1998;132(1):32-8.

28. Seckl JR, Walker BR. $11 \beta$-hydroxysteroid dehydrogenase type 1 - a tissue-specific amplifier of glucocorticoid action. Endocrinology. 2001;142:1371-6.

29. Jensen EC, Gallaher BW, Breier BH, Harding JE. The effect of a chronic maternal cortisol infusion on the late-gestation fetal sheep. J Endocrinol. 2002;174:27-36.

30. Fowden AL, Li J, Forhead AJ. Glucocorticoids and the preparation for life after birth: are there long-term consequences of the life insurance. Proc Nutr Soc.1998;57:113-22.

31. Sugden MC, Langdown ML, Munns MJ, Holness MJ. Maternal glucocorticoid treatment modulates placental leptin and leptin receptor expression and materno-fetal leptin physiology during late pregnancy, elicits hypertension associated with hyperleptinemia in the early growth retarded adult offspring. Eur J Endocrinol. 2001;145:529-39.

32. Smith JT, Waddell BJ. Leptin receptor expression in the ratplacenta: changes in $\mathrm{Ob}-\mathrm{Ra}, \mathrm{Ob}-\mathrm{Rb}$ and $\mathrm{Ob}-\mathrm{Re}$ with gestational age and suppression by glucocorticoids. Biol Reprod. 2002;67:1204-10. 
33. Smith JT, Waddell BJ. Developmental changes in plasma leptin and hypothalamic leptin receptor expression in the rat: peripubertal changes and the emergence of sex differences. J Endocrinol. 2003;176: 313-9.

34. Edwards CRW, Benediktsson R, Lindsay RS, Seck JR. Dysfunction of the placental glucocorticoid barrier: A link between the foetal environment and adult hypertension? Lancet. 1993;341:355-7.

35. Seckl JR. Physiologic programming of the fetus. Clin Perinatol. 1998;25:939-62.

36. Philips DI, Barker M, Fall CH, Seckl JR, Whorwood CB, Wood PJ. Walker BR. Elevated plasma cortisol concentrations: a link between low birth weight and the insulin resistance syndrome? J Clin Endocrinol Metab. 1998;83:757-60.
37. Barker DJ. In utero programming of cardiovascular diseases. Theriogenology. 2000;53:555574.

38. Lesage J, Blondeau B, Grino M, Bréant B, Dupouy JP. Maternal undernutrition during late gestation induces fetal overexposure to glucocorticoids, intrauterine growth retardation and disturbs the hypothalamopituitary adrenal axis in the newborn rat. Endocrinology. 2001;142:1692-702.

39. Fowden AL, Forhead AJ. Endocrine mechanisms of intrauterine programming. Reproduction. 2004;127:515-26.

40. Emelike CU, Anyaehie U SB, Iyare EE, Obike CA, Eleazu CO, Chukwuma C. Acute and sub-acute toxicity studies on Combretum dolichopetalum Engl. \& Diels leaves. Slov Vet Res. 2020;57(3):105-14. 